\title{
Adductor laryngeal exhaling dystonia in progressive supranuclear palsy
}

回的

\section{Supplemental data at Neurology.org}

An 80-year-old woman with a 7-year history of progressive supranuclear palsy had periodic dyspnea attacks that lasted for several hours. During these attacks, she involuntarily groaned because she could barely exhale but could inhale (video 1 on the Neurology ${ }^{\circledR}$ Web site at Neurology.org). When she was instructed to pronounce words, she could do this voluntarily and phonation enabled her to exhale. Laryngoscopy revealed that her vocal cords opened during inspiration but closed during expiration (video 2). This was a case of laryngeal dystonia ${ }^{1,2}$ and may be a rare example of respiratory disorders resulting from adductor laryngeal exhaling dystonia (appendix e-1).

Kazuyuki Kawamura, MD, Yoshiharu Arii, MD, Toshio Inui, MD, Takao Mitsui, MD

From Tokushima National Hospital, National Hospital Organization, Kamojima, Yoshinogawa, Japan.

Author contributions: Dr. Kawamura: acquisition of data, analysis or interpretation of data, drafting/revising the manuscript for content. Dr. Arii: acquisition of data, analysis or interpretation of data. Dr. Inui: analysis or interpretation of data, study supervision. Dr. Mitsui: analysis or interpretation of data, drafting/revising the manuscript for content, study supervision.

Acknowledgment: The authors thank Dr. Jiro Udaka for providing technical support in video laryngoscopy and Koji Kawamichi for assistance in video recording of the patient.

Study funding: No targeted funding reported.

Disclosure: The authors report no disclosures relevant to the manuscript. Go to Neurology.org for full disclosures.

Correspondence to Dr. Kawamura: kawamura@tokushima-nh.hosp.go.jp

1. Zwirner P, Dressler D, Kruse E. Spasmodic laryngeal dyspnea: a rare manifestation of laryngeal dystonia. Eur Arch Otorhinolaryngol 1997;254:242-245.

2. Panegyres PK, Hillman D, Dunne JW. Laryngeal dystonia causing upper airway obstruction in progressive supranuclear palsy. J Clin Neurosci 2007;14:380-381. 


\section{Neurology}

\section{Adductor laryngeal exhaling dystonia in progressive supranuclear palsy Kazuyuki Kawamura, Yoshiharu Arii, Toshio Inui, et al. Neurology 2015;84;545 \\ DOI 10.1212/WNL.0000000000001206}

This information is current as of February 2, 2015

\begin{tabular}{|c|c|}
\hline $\begin{array}{l}\text { Updated Information \& } \\
\text { Services }\end{array}$ & $\begin{array}{l}\text { including high resolution figures, can be found at: } \\
\text { http://n.neurology.org/content/84/5/545.full }\end{array}$ \\
\hline Supplementary Material & $\begin{array}{l}\text { Supplementary material can be found at: } \\
\text { http://n.neurology.org/content/suppl/2015/02/01/WNL.0000000000001 } \\
\text { 206.DC1 } \\
\text { http://n.neurology.org/content/supp1/2015/02/01/WNL.0000000000001 } \\
\text { 206.DC2 }\end{array}$ \\
\hline References & $\begin{array}{l}\text { This article cites } 2 \text { articles, } 0 \text { of which you can access for free at: } \\
\text { http://n.neurology.org/content/84/5/545.full\#ref-list- } 1\end{array}$ \\
\hline Subspecialty Collections & $\begin{array}{l}\text { This article, along with others on similar topics, appears in the } \\
\text { following collection(s): } \\
\text { Dystonia } \\
\text { http://n.neurology.org/cgi/collection/dystonia } \\
\text { Progressive supranuclear palsy } \\
\text { http://n.neurology.org/cgi/collection/progressive_supranuclear_palsy }\end{array}$ \\
\hline Permissions \& Licensing & $\begin{array}{l}\text { Information about reproducing this article in parts (figures,tables) or in } \\
\text { its entirety can be found online at: } \\
\text { http://www.neurology.org/about/about_the_journal\#permissions }\end{array}$ \\
\hline Reprints & $\begin{array}{l}\text { Information about ordering reprints can be found online: } \\
\text { http://n.neurology.org/subscribers/advertise }\end{array}$ \\
\hline
\end{tabular}

Neurology ${ }^{\circledR}$ is the official journal of the American Academy of Neurology. Published continuously since 1951, it is now a weekly with 48 issues per year. Copyright () 2015 American Academy of Neurology. All rights reserved. Print ISSN: 0028-3878. Online ISSN: 1526-632X.

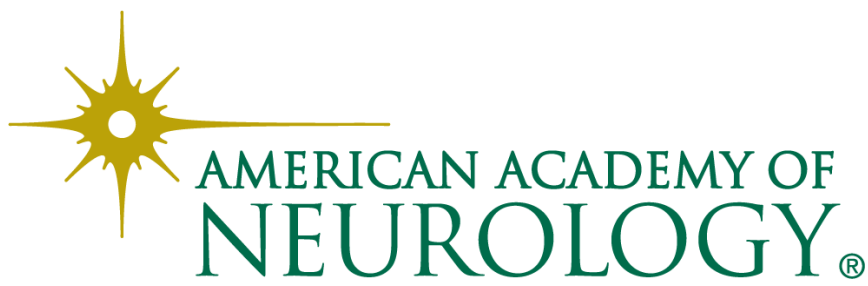

